Article

\title{
Dynamic Capability of the Firm as Driver of Green Supply Chain Management Implementation
}

\author{
Bomi Song and Donghyun Choi * \\ School of Air Transportation and Logistics, Korea Aerospace University, Goyang-si, Gyeonggi-do 10540, Korea; \\ bmsong@kau.ac.kr \\ * Correspondence: dchoi@kau.ac.kr; Tel.: +82-2-300-0374
}

Received: 1 June 2018; Accepted: 14 July 2018; Published: 19 July 2018

\begin{abstract}
Eco friendly management has received attention from business as an important competitive source. Thus, an emerging body of studies is interested in the implementation of green supply chain management (GSCM). Previous research in this field has acknowledged the importance of GSCM. However, the capability that enables a firm to successfully adopt GSCM is not well researched. This study empirically examines dynamic capability as an antecedent of GSCM, with the aim of proposing a causal relationship between dynamic capability and GSCM. The result of this study shows that implementing GSCM with dynamic capability enables a firm to achieve successful GSCM practices, and that this in turn leads to enhanced organizational performance.
\end{abstract}

Keywords: dynamic capability; environmental performance; economic performance; green supply chain; sustainability

\section{Introduction}

Developing an environmental friendly supply chain is becoming a source of sustainability and competitiveness for firms [1,2]. As the portion of procurement from outside of firms is increasing, a firm must deal with many suppliers from different countries. While many suppliers are located in Asia, Asian countries have various ways of joining eco-friendly management systems [3]. For example, Samsung electronics has one of its main factories in Vietnam, while suppliers for this operation are located in many different countries including Korea, China, and Vietnam. Thus, not only understanding eco-friendly requirements for one country but also proactively analyzing environmentally friendly strategies across the entire supply chain is essential [4]. Since supply chain members are located in places having different regulations, firms might have different regulations to manage their own facilities. Thus, firms should seek to rapidly understand their suppliers' standards for green management and act on any issues created by misalignment in green management. If suppliers of the firm fail to follow a required standard of the consumer market, the firm's final product will face problems. Thus, building strong inter-firm knowledge sharing routines with partners within the supply chain participating in green initiatives is an important factor in rapidly adopting and managing a green supply chain system. With strongly tied knowledge sharing routines, firms will be able to obtain information from partners rapidly. Although firms realize the importance of strong relationships with partners to accomplish continuous improvements in green management, they still have difficulties in managing such relationships. A stream of research in green supply chain management (GSCM) has sprung up to cope with supply chain challenges in achieving sustainable management [5-7].

Implementing green supply chain practice has been referred to as a refining and elaborating process and structure designed to implement and maintain sustainable competitive advantages $[8,9]$. In the early stages of GSCM, studies focused on strategies to quickly respond to changes in the business environment such as regulations, stake holder pressure, and ethical concerns [10]. However, 
recent studies view the proactive capabilities of "greening" as able to create competitive advantage through successful GSCM implementation [7,11-14]. As emphasized in the dynamic capabilities of firms, an organization develops competitive advantage through the improvement of organizational capabilities associated with a proactive eco-friendly strategy, which requires a continuous adopting process $[15,16]$. Thus, firms should understand or predict market changes created by green management beforehand to generate competitive advantages in the market. Thus, studies have sought to suggest factors that lead to successful GSCM [10,17-20].

Since a "greening" process requires a different or innovative process of managing its organization and supply chain compared to traditional processes, firms need capabilities of sensing and adopting management processes sensitive to changing market needs, which requires not only knowledge of customers but also knowledge of competitors. Understanding customers and competitors enables firms to follow changes in the market. Few studies have considered organization operations process, which is derived from dynamic capabilities [20-22], to address how the capability of a firm plays a critical role in implementing GSCM. While firms might have a unique set of assets, most of them may be visible assets consisting of production factors or generic assets [18,23]. However, competitive advantage does not reside in such assets [24]. Instead, organizational capabilities which uniquely use these assets can generate competitive advantage [25]. Especially in the dynamic market, a fixed set of resources might provide a highly efficient routine process under one environment but would not provide sustainable competitive advantage. Sources of competitive advantage from previous business environments would not work in the green initiative era. Also, since this market dynamic is still changing, firms need a good sense of market changes and efficient process to adopt changes in organization. Thus, organizations require dynamic capabilities to sustain competitive advantage in the green era. Previous studies have considered dynamic capabilities from the perspective of an individual firm [26], not considering the supply chain aspect (e.g., relationship with supplier). However, green supply chain management should consider a firm's capability of resource integration with its supplier. Thus, we theorized dynamic capabilities in two different aspects: market orientation and relational capabilities.

The goal of this study is to identify the causal relationship between capability of understanding and sensing market changes and adopting GSCM practices, and the impact of GSCM practice on two different aspects of performance. In this paper, we investigate which features of dynamic capability affect the adoption of GSCM practices and show the impact of GSCM on performance. The paper is organized as follows. In Section 2, we review the relevant literature and develop hypotheses. In Section 3, we discuss the data collection process and describe the data. In Sections 4 and 5, we analyze and discuss the results. Finally, we conclude with some managerial insights and directions for future work in Section 6.

\section{Literature Review}

In this section, the literature is reviewed by focusing on the green supply chain initiative so as to identify antecedents of GSCM practice. The theoretical model postulated is shown in Figure 1. It is hypothesized that organizational performance is impacted by proactive GSCM strategy which, in turn, is driven by two dynamic capability elements, market orientation and relational capability. We discuss the rationale for the hypothesized model, definitions, and background below. 


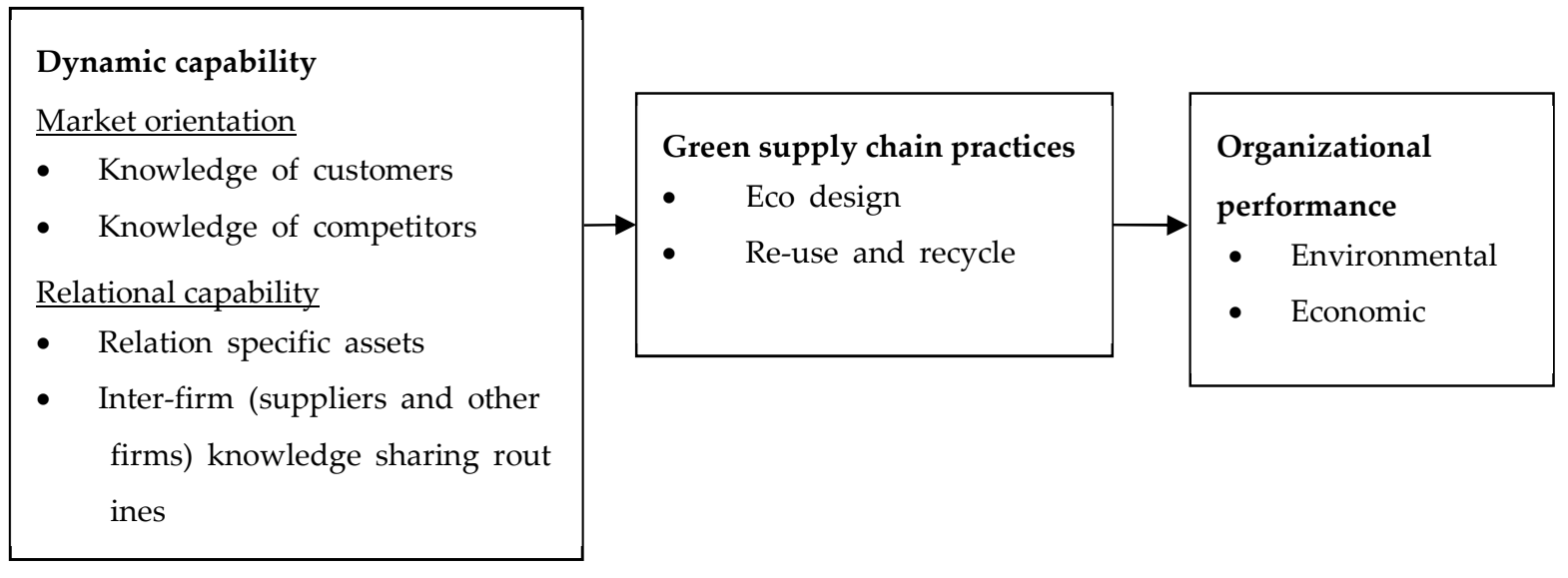

Figure 1. Proposed model structure.

\subsection{Green Supply Chain Practice}

Researchers and practitioners understand the importance of the green supply chain and they are paying more attention to the topic. The impact of eco-friendly management on competitive advantage has been studied in various ways $[6,27,28]$. Previous studies focused on how to monitor its partners to participate in environmental regulations compliance for reducing and minimizing harmful outcomes [29]. In this research stream, green operations have been considered an unrewarding investment and focus has shifted to reducing the harmful outcomes of an individual operation. A growing number of studies have proposed that implementing GSCM is a source of a competitive advantage and it can positively impact organizational performance [30-32].

A stream of studies has proposed that it is important to implement proactive GSCM practices $[33,34]$, such as collaborating with suppliers or participating in early supplier involvement programs to develop eco-friendly products $[6,13,30]$. Pursuing green management, firms can achieve lean management, which is also a way to improve performance [35]. To achieve such integration, the involvement of suppliers in GSCM practice is crucial. Also, studies have suggested that resource reconfiguration capability is a precedence factor for successful GSCM $[19,26]$. GSCM practices have been measured in various variables, including Internal Environmental Management (IEM), Green purchasing, Eco design, and investment recovery, re-use, and recycling [32]. In this study, we used Eco design to measure IEM, green purchasing, Eco design, and re-use and recycling to measure investment recovery and reuse and recycling. We focus on two GSCM factors: eco design and re-use through recycling $[32,36]$ because they cover all phases of the product life cycle related to GSCM. Eco design is involved in the early phase of the product life cycle while re-use and recycling affect the later stages of the product life cycle.

\subsubsection{Eco Design}

Eco design, also known as design for the environment, refers to the systematic integration of technical improvements in the supply chain to reduce harmful impact on the environment [32]. This design process affects products' whole life cycle. To design eco products, it is important to recognize that environmental aspects must be considered in the early phases of design, such as the planning and conceptual design phase [36]. It is estimated that over $80 \%$ of all product-related environmental impact stems from the design phase of a product $[37,38]$. Thus, eco design needs to be approached in an integrated perspective, from purchasing to delivery to customers. The manufacturing company must cooperate with its suppliers to design environmentally friendly products by reflecting market needs or competitors' strategy [39,40]. Coordination between the buyer and suppliers can be reinforced through knowledge sharing routines, because new trends in market changes can reside in suppliers [41]. Also, relation asset specificity has been proven to positively affect performance of 
the supply chain [42] through reduced coordination time with partners, enabling the manufacturer to produce more market oriented products (e.g., eco design).

\subsubsection{Re-Use and Recycling}

Re-use and recycling have become more popular due to environmental regulations and social responsibility. Re-use and recycling help firms reduce cost and waste. Re-use is a remanufacturing process that recovers some parts of the original products [43]. Recycling refers to a firm's strategy for collecting and breaking down products into raw materials [30,44]. These two approaches prevent potential waste, reduce the consumption of raw materials, and decrease pollution. A number of studies have presented evidence that re-use and recycling positively affect minimizing harmful waste and lengthen the life cycle of the product or material [13]. Coordination and communications between the buyer and suppliers play a critical role in executing re-use and recycling policies in the supply chain, since the re-use and recycling process is complex [45] and requires a strong tie within supply chain.

\subsection{Dynamic Capability}

Dynamic capabilities have been studied to understand how and why a certain firm has competitive advantage in the rapidly changing environment [24,46-48]. Dynamic capabilities refer to an extension of the Resource Based View (RBV), which suggests that firms with resources that satisfy VRIN (valuable, rare, imperfectly imitable, non-substitutable) criteria allow them to attain competitiveness $[24,49]$. Teece et al. [47] identified "dynamic" as the ability to "renew competences so as to achieve congruence with the changing business environment" and "capabilities" as "the key role of strategic management in appropriately adapting, integrating, and reconfiguring internal and external organizational skills, resources, and functional competence to match the requirements of a changing environment." Thus, a number of studies have argued that dynamic capability is an antecedent of rents that bring competitive advantage in a dynamic market, because it plays a critical role in adapting and even capitalizing on rapidly changing environments [50].

As the complexity of the business environment increases, especially in its need for green management, firms compete based on the ability to continually improve the business process with their dynamic capabilities $[20,21]$. The continuous improvement process refers to a systematic effort to search for and utilize new versions of the process and repeatedly refining it. To attain this stage, firms employ routine methods of carrying out processes, which include alternative strategies in response to environmental changes [51]. These processes can be accomplished by organizational learning through various channels, such as customers, competitors, and partners. Thus, the ability to secure knowledge exchange channels can be derived through dynamic capabilities.

Studies have operationally defined dynamic capability and have measured it using various variables $[48,52,53]$. In line with many previous studies, we believe dynamic capability is manifested in relational capability and market orientation [54,55]. Through relational capabilities firms can achieve continuous rents from their partners. In this sense, as Helfat et al. [54] stated, "relational capability can viewed as a type of dynamic capabilities with the capacity to purposefully create, extend, or modify the firm's resource base, augmented to include the resource of its alliance partner." Thus, we include relational capacities in measuring dynamic capabilities. Also, since response to changing market circumferences is a critical factor in dynamic capacities, studies view market orientation as able to be transformed into dynamic capabilities [56].

\subsubsection{Relational Capability}

As firms need to cope with the rapidly changing environment, a number of firms have tried to develop competitiveness through inter-firm partnerships [57,58]. Particularly, as global sourcing opportunities increase, firms face a dynamic market and need to develop relationships with suppliers and other value chain partners from all over the world. Pressured by globalization, along with changes in regulations and technological factors (e.g., green technology), firms resort 
to securing access to complementary capabilities from their alliance organizations (i.e., relational capability) [59]. To refine relational capabilities, studies suggest that interrelation-specific assets and knowledge sharing are critical when firms are in partnership [60]. To enhance green innovation capabilities, many manufacturers count on partner firms, customers, and their suppliers for green product development. To develop such capabilities, knowledge sharing for GSCM to develop green products with partners is critical [61,62]. An emerging body of studies has identified that the inter-firm knowledge sharing routine can help knowledge creation, transfer, and combination $[63,64]$. Through this routine process, firms can exchange their knowledge for double-loop learning. This process can create new knowledge related to green operations. Communication between the buyer and suppliers promote inter-organizational learning, which can help create competitive advantage to all involved firms $[65,66]$.

Relation specific assets refer to those of a firm customized to the relationship with another partner, so that the combination of assets is idiosyncratic [67]. The specificity of a relational asset is subject to the length of time that the firms have been in partnership with each other. This asset enables alliance partners to attain an efficient cooperative innovation system in the fast changing environment [68].

Relational capability can be viewed as a type of dynamic capability which can purposefully create, extend, or modify the firm's resource base, augmented to include the resources of alliance partners. For the purpose of this study, we consider only the relationship with suppliers. In this study, we deem relational capability to be a higher order construct of the relation specific asset and the inter-firm knowledge sharing routine. Thus, the following hypothesis is proposed.

Hypothesis 1 (H1). Relational capability positively affects market orientation.

Hypothesis 2 (H2). Relational capability positively affects successful implementation of GSCM.

\subsubsection{Market Orientation}

Studies have proposed that market orientation (MO) can create superior performance [69-71]. $\mathrm{MO}$ provokes continuous and proactive actions to meet customer needs in an era of hyper-competitiveness [72]. Through this innovation process, a firm can create organizational capabilities that render a source of comparative advantage.

Based on RBV, the firm with superior MO is expected to be effective in sensing consumers' needs and delivering values based on their interests and needs [72-74]. This is because the market-oriented firm has advantage in managing resources more effectively and efficiently based on market information [75]. Also, market-oriented firms can sense opportunities using information from its customers and competitors, and thus be able to proactively alter strategy according to business environmental changes [76,77]. Thus, studies of market orientation emphasize the importance of customer and competitor knowledge $[73,75,78]$. Customer knowledge refers to how well and correctly a firm is understanding customer needs [78,79]. A firm with superior competitor knowledge can act on competitor strategies rapidly. Some studies have argued that since the market is dynamic, market-oriented firms can attain dynamic capabilities by facilitating the process of acquiring, transferring, and institutionalizing market information $[55,56,80]$.

For the purpose of this study, we consider MO as a higher order construct of customer and competitor orientation. We propose the following hypothesis.

Hypothesis 3 (H3). Market orientation positively affects successful implementation of GSCM. 


\subsection{GSCM and Organizational Performance}

Linking GSCM and supply chain performance has been studied from different points of view [81]. Traditionally, key indicators of organizational performance have been economic performance, operational efficiency, and quality [82]. However, as environmental issues gain popularity, environmental performance has become important [83]. Recently, the green movement is causing consumers to care about purchasing environmentally friendly products. Environmental performance includes indicators of controlling harmful waste such as carbon monoxide emissions, waste water, or solid waste [33]. Berry and Rondinelli [84] suggested that proactive environmental management policy is effective in reducing harmful waste. Following previous studies, our study uses measurements such as reducing harmful outcomes (i.e., re-use through recycling) and eco-friendly design by implanting GSCM $[32,33]$. Those two factors can encompass the whole life cycle of production. Working together to achieve a successful green supply chain, firms across the supply chain are able to identify or find factors that are harmful to environmental performance. Thus, we propose the following hypothesis.

Hypothesis 4 (H4). GSCM implementation positively affects a firm's environmental performance.

Economic performance is typically the most crucial factor for firms to implement new strategy. Since GSCM is one of new strategies for firms, it is important to find empirical support between environmental management practices and economic performance [85]. Studies have argued that success in addressing environmental issues may enable firms to reduce risk and in turn increase innovation and profitability $[82,84]$. Also, public announcements about the firm's green management practices positively affect its image and economic performance [28,86]. Studies have argued GSCM provide firms with better profit margin through establishing new standards [87]. Thus, the following hypothesis is proposed.

Hypothesis 5 (H5). GSCM implementation positively affects the organization's economic performance.

Figure 2 presents the complete research model with hypotheses. It should provide a concise and precise description of the experimental results, their interpretation, as well as the experimental conclusions that can be drawn.

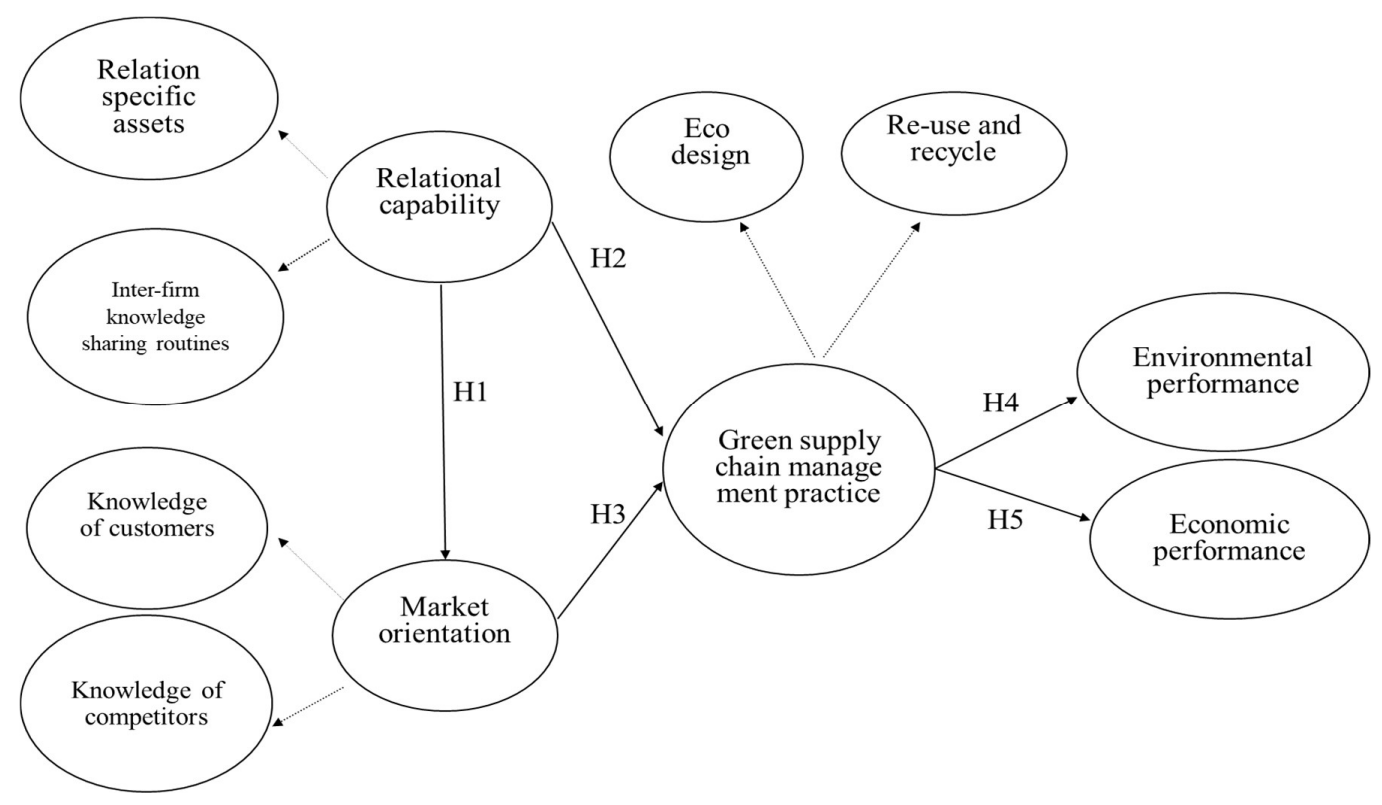

Figure 2. The research model. 


\section{Research Methods}

\subsection{Sample}

The data for this study was collected in South Korea. There are several reasons why we studied manufacturers and suppliers in South Korea. First, South Korea has emerged as among the major global manufacturing nations. According to 2017 statistics of the international Monetary Fund (IMF), the gross domestic product (GDP) of South Korea ranked 11th in the world. Samsung, Hyundai, and LG are leading global firms. As a matter of fact, Samsung Electronics has become the world's largest electronics firm based on annual revenue, and has pushed forward its green operation strategy as its key competitive advantage. For example, Samsung reported that it had established its four key strategies for green management: cutting carbon emissions, expanding eco tech-embedded product line-ups, investing to build green operations, and strengthening partnerships with suppliers for green management. Second, keen competition over the last decade has compelled firms to grow the capability to adopt to global requirements and standards. As most of South Korean firms depend on global trade ( $45 \%$ of Korean GDP is from trade), manufacturers and suppliers in South Korea are sensitive to global environmental requirements and standards. With the requirements of sustainable development and globalization, Korean firms have understood the importance of GSCM.

\subsection{Survey Instrument}

The items used in the questionnaire were developed based on an extensive literature review. A seven-point Likert scale with anchors ranging from strongly disagree (1) to strongly agree (7) were used in order to ensure high statistical variability among survey responses. We employed the double translation protocol for the survey questionnaire. Initially, an English version of the survey items was developed and pre-tested for content validity in two stages. In the first stage, we asked three experienced researchers to review the survey items for appropriateness and ambiguity of items. After feedback was received, the survey questionnaires were revised to improve measurement appropriateness. In the next stage, the survey questionnaires were sent to four SCM practitioners. They reviewed whether the questionnaire items were proper for their current business situation. The pre-test process resulted in a set of survey questionnaires that exhibit high content validity. In the next step, we translated the questionnaire into Korean. A bilingual POM faculty proofread both versions and gave feedback on some ambiguities. Based on the comments, we revised the survey and pilot tested it with 20 Korean firms.

We distributed the questionnaire through a web-based survey. An increasing number of studies have used web-based surveys in recent years, as respondents find these easy to answer. Web-based surveys have been considered more convenient than the conventional mail-based surveys with substantially fewer missing responses [88].

\subsection{Data Collection}

Surveys were sent out mainly to SCM managers of 890 manufacturing companies. We obtained the sample firms and their supply chain managers from The Korean Logistic Association Database. However, some respondents were from production and environment management teams. The survey yielded 230 usable responses (a response rate of $25.8 \%$ ), a desired rate for a supply chain management survey [69]. The sample consists of $62.6 \%$ from miscellaneous manufacturing industries, automobile hardware, metal, and manufacturing, and computer equipment, $24.8 \%$ from metal, rubber, and plastics, and $12.6 \%$ from transportation services. 


\section{Result}

\subsection{Measurement Model}

We employed structural equation modelling (SEM) using AMOS 18.0 to test and analyze the hypotheses. We analyzed the data to establish the dimensional structures. First, we tested content validity to the extent to which a measure reflects every single facet of a construct. To establish convergent and discriminant validity, a confirmatory factor analysis (CFA) was conducted. The overall model fit was evaluated using fit indices from various fit criteria (RMSEA $=0.07 ; \mathrm{CFI}=0.95$; GFI = 0.871; CMIN/DF = 2.13) [89-91]. The result of CFA shows CFI met the recommended value (0.95) and RMSEA and GFI approximated the recommended values (0.06 and 0.95, respectively) [92].

Composite reliability (CR) was used to assess the reliability of the constructs. Both the AVE and CR exceeded recommended values of 0.5 and 0.6 , respectively [89] (Table 1). Convergent validity was evaluated by item factor loadings and items' squared multiple correlation coefficients. Fornell and Larcker [93] suggest that convergent validity exists when item factor loadings are greater than 0.7 and items' squared multiple correlation coefficients are greater than 0.5 (See Table 2). In this study, after items are deleted (com1, col 3, col 4, share 4, re 1, ecoper 1, and fin 1), all loadings exceeded 0.7. The average variance extracted (AVE) was compared with the squared correlation between constructs to test discriminant validity [94]. On Table 2, AVE of each construct calculated on the diagonal and correlation coefficients between the latent variables are shown. Fornell and Larcker [93] prescribe that the squared correlation between latent variables should be less than AVE on diagonal to show discriminant validity. Table 2 shows that every squared correlation between constructs was greater than AVE of each construct. Results of CFA are presented in Tables 1 and 2. The rationale for the items used in this study is presented in Appendix A.

Table 1. Items, factor loadings.

\begin{tabular}{|c|c|c|c|c|c|}
\hline Construct & Items & $\begin{array}{l}\text { Standardized } \\
\text { Loading }\end{array}$ & $\begin{array}{l}\text { Standardized } \\
\text { Error }\end{array}$ & $\begin{array}{l}\text { Composite } \\
\text { Reliability }\end{array}$ & $\begin{array}{l}\text { Variance } \\
\text { Extracted }\end{array}$ \\
\hline \multirow{4}{*}{ Customer } & Cus1 & 0.936 & 0.460 & \multirow{4}{*}{0.872} & \multirow{4}{*}{0.630} \\
\hline & Cus2 & 0.808 & 0.533 & & \\
\hline & Cus3 & 0.833 & 0.425 & & \\
\hline & Cus4 & 0.900 & 0.259 & & \\
\hline \multirow{3}{*}{ Competitor } & Com2 & 0.839 & 0.410 & \multirow{3}{*}{0.893} & \multirow{3}{*}{0.736} \\
\hline & Com3 & 0.938 & 0.179 & & \\
\hline & Com4 & 0.909 & 0.274 & & \\
\hline \multirow{2}{*}{$\begin{array}{c}\text { Specific } \\
\text { investment }\end{array}$} & Col1 & 0.930 & 0.239 & \multirow[b]{2}{*}{0.800} & \multirow[b]{2}{*}{0.668} \\
\hline & $\mathrm{Col} 2$ & 0.823 & 0.528 & & \\
\hline \multirow{3}{*}{$\begin{array}{l}\text { Sharing } \\
\text { Knowledge }\end{array}$} & Share 1 & 0.856 & 0.419 & \multirow{3}{*}{0.855} & \multirow{3}{*}{0.663} \\
\hline & Share 2 & 0.888 & 0.295 & & \\
\hline & Share 3 & 0.853 & 0.429 & & \\
\hline \multirow{3}{*}{ Eco design } & Eco 1 & 0.857 & 0.424 & \multirow{3}{*}{0.858} & \multirow{3}{*}{0.668} \\
\hline & Eco 2 & 0.896 & 0.340 & & \\
\hline & Eco 3 & 0.880 & 0.387 & & \\
\hline \multirow{2}{*}{$\begin{array}{l}\text { Re use and } \\
\text { recycle }\end{array}$} & $\operatorname{Re} 2$ & 0.840 & 0.416 & \multirow{2}{*}{0.790} & \multirow{2}{*}{0.653} \\
\hline & $\operatorname{Re} 3$ & 0.865 & 0.355 & & \\
\hline \multirow{3}{*}{$\begin{array}{l}\text { Environmental } \\
\text { performance }\end{array}$} & Eco per2 & 0.909 & 0.285 & \multirow{3}{*}{0.870} & \multirow{3}{*}{0.691} \\
\hline & Eco per3 & 0.860 & 0.381 & & \\
\hline & Eco per4 & 0.876 & 0.376 & & \\
\hline \multirow{3}{*}{$\begin{array}{c}\text { Economic } \\
\text { performance }\end{array}$} & Fin 2 & 0.843 & 0.500 & \multirow{3}{*}{0.881} & \multirow{3}{*}{0.711} \\
\hline & Fin 3 & 0.929 & 0.213 & & \\
\hline & Fin 4 & 0.918 & 0.267 & & \\
\hline
\end{tabular}


Table 2. Discriminant validity.

\begin{tabular}{ccccccccccc}
\hline & Mean & SD & cus & com & col & share & eco & re & ecobe & pro \\
\hline cus & 5.533 & 1.068 & 0.630 & & & & & & & \\
com & 5.089 & 1.134 & 0.397 & 0.736 & & & & & & \\
col & 5.193 & 1.228 & 0.352 & 0.557 & 0.668 & & & & & \\
share & 5.209 & 1.123 & 0.350 & 0.584 & 0.619 & 0.663 & & & & \\
eco & 5.256 & 1.191 & 0.462 & 0.656 & 0.373 & 0.627 & 0.668 & & & \\
re & 5.130 & 1.106 & 0.360 & 0.471 & 0.324 & 0.501 & 0.452 & 0.653 & & \\
ecobe & 5.288 & 1.161 & 0.421 & 0.615 & 0.536 & 0.588 & 0.638 & 0.456 & 0.691 & 0.711 \\
pro & 4.633 & 1.199 & 0.355 & 0.276 & 0.287 & 0.306 & 0.298 & 0.328 & 0.350 & \\
\hline
\end{tabular}

\subsection{Structure Model Analysis and Results}

The structural model showing the conceptual framework along with the parameter estimates is presented in Figure 3. Hypotheses testing and significance of the link are summarized in Table 3. As shown in Table 3, the effect of relational capability on market orientation was significant and positive $(\gamma=0.957, p<0.01)$. The result provided strong support for Hypothesis 1 . Thus, firms in the supply chain with strong relationships with partners are more likely to exhibit a high level of market orientation. The path from market orientation to green supply chain practice show significant relationship $(\gamma=0.941, p<0.01)$. Therefore, Hypothesis 2 was also supported. This implies that the firm's knowledge of the market affects implementing GSCM practice, because the market-oriented firm can sense market requirements rapidly. However, the effect of relation capability on GSCM practice was not significant $(p>0.05)$; therefore Hypothesis 3 was not supported. However, relational capability had an indirect effect on GSCM practice $(\gamma=0.901, p<0.05)$. Thus, relational capability affects GSCM through market orientation. The effect of GSCM practice on environmental performance was significant $(\gamma=1.264, p<0.01)$. Thus, Hypothesis 4 was supported. Hypothesis 5 proposed a positive impact of GSCM practice on economic performance, and our result also provided significant support for this relationship $(\gamma=0.921, p<0.01)$. The results are shown in Figure 3 and Table 3 .

Table 3. Statistical results.

\begin{tabular}{|c|c|c|c|c|c|}
\hline & Path & & Direct Effects & Indirect Effects & $\begin{array}{l}\text { Hypotheses } \\
\text { Testing }\end{array}$ \\
\hline Relation capability & $\rightarrow$ & $\begin{array}{c}\text { Market } \\
\text { orientation }\end{array}$ & $0.957^{* *}$ & & H1 supported \\
\hline Relation capability & $\rightarrow$ & $\begin{array}{l}\text { Green supply } \\
\text { chain practice }\end{array}$ & $(0.148)$ & $0.901 *$ & $\begin{array}{l}\text { H2 partially } \\
\text { supported }\end{array}$ \\
\hline Market orientation & $\rightarrow$ & $\begin{array}{l}\text { Green supply } \\
\text { chain practice }\end{array}$ & $0.941^{* *}$ & & H3 supported \\
\hline $\begin{array}{c}\text { Green supply chain } \\
\text { practice }\end{array}$ & $\rightarrow$ & $\begin{array}{l}\text { Environmental } \\
\text { performance }\end{array}$ & $1.264^{* *}$ & & H4 supported \\
\hline $\begin{array}{c}\text { Green supply chain } \\
\text { practice }\end{array}$ & $\rightarrow$ & $\begin{array}{c}\text { Economic } \\
\text { performance }\end{array}$ & $0.921^{* *}$ & & H5 supported \\
\hline
\end{tabular}




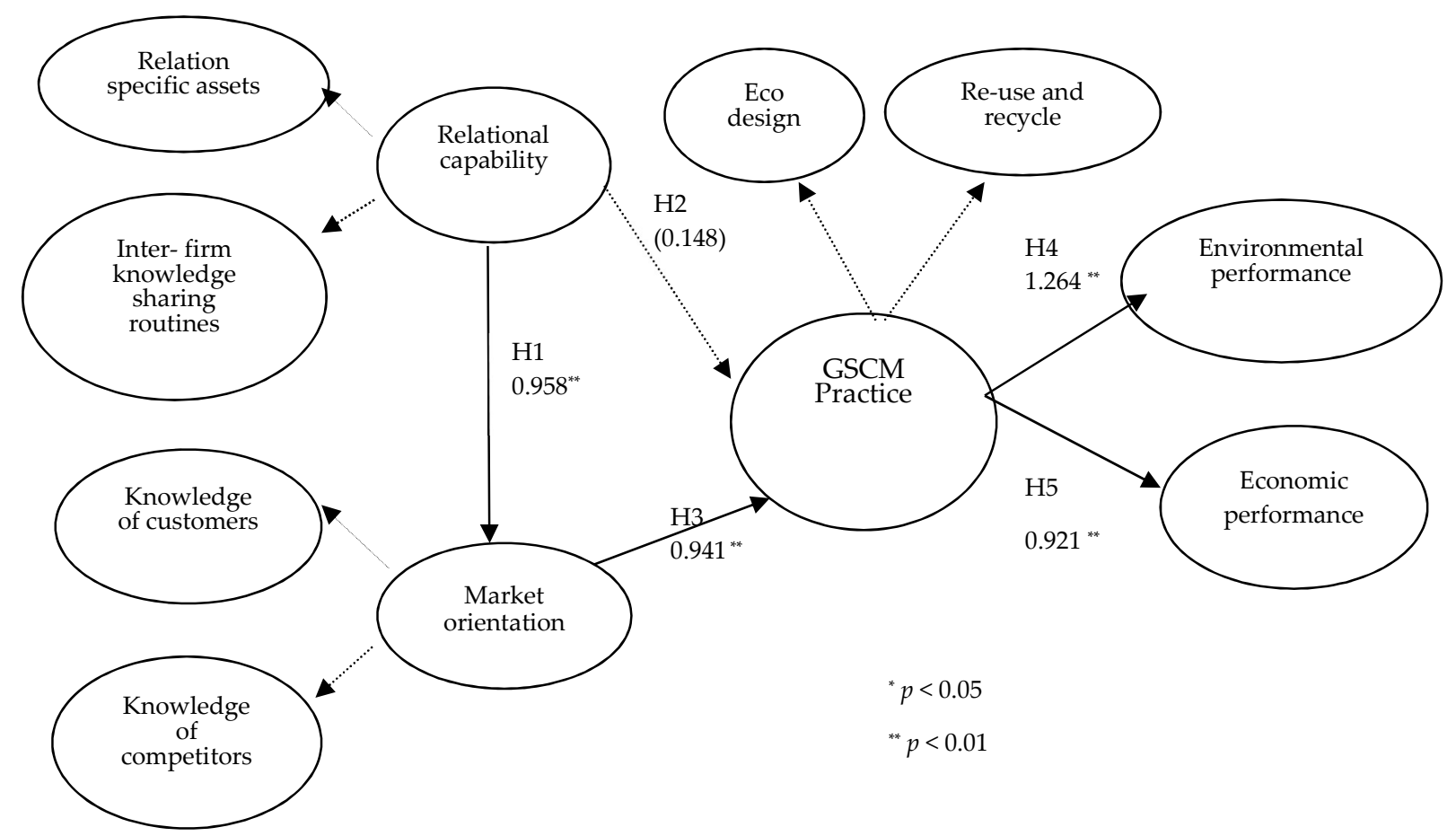

Figure 3. Research model result.

\section{Discussion and Conclusions}

Recently, China's ban on waste imports has had a huge impact on many countries, including Korea. China has been the world's largest importer of recyclable materials, such as plastics and papers. China imported 7.4 million tons of waste plastics in 2016. In this changing situation, firms proactively implementing GSCM can achieve superior performance by managing their supply chain prior to such changes. Studies have supported GSCM impact on achieving profit and increasing market share by lowering firm's environment related costs while increasing eco-friendly operations. Studies have found that successful GSCM implementation can benefit the firm, particularly as a revenue driver [6]. However, most previous GSCM related studies have not investigated which capability of firms can lead to successful GSCM in a dynamic market. This study proposed dynamic capability of firms as an antecedent of successful GSCM implementation, which in turn affects organizational performance. We measured relational capabilities and market orientation to define dynamic capabilities. This study makes an academic contribution by measuring dynamic capability based on two important constructs in order to sense market changes and reconfigure its process by applying market requirements.

Market orientation and relational capability conceptualize synergies that arise from involving partners, suppliers, and customers in implementing GSCM practice. Market orientation is found to influence GSCM practice. This result illustrates that firms should realize that acquiring knowledge about the market and competition is important. Using various information channels, the firm can sense the pulse of the market rapidly. This capability enables the firm to rapidly respond to market needs (i.e., green management) and anticipate opportunities emerging from the green tide. Especially in this rapid changing market environment, it is necessary to have this information acquiring routine from partners. Relational capability did not show a direct impact on GSCM practice in our study. As the literature stream on the relationship between inter-organizational involvement and firm performance indicates, examining the relationship effect on rent or performance may lead to inconsistent and ambiguous results. As the results indicated, market orientation mediates the relationship between relational capability and GSCM practice. That is, a firm's efforts to collaborate with supply chain members will not pay off if the firm is not market oriented. In addition, 
through complex communication, coordination, and conflict resolution processes, the firm can obtain a shared interpretation of the information, which enables swift and decisive actions to exploit opportunities [95]. To better represent these interdependencies, our study conceptualized collaborative competence as the synergy resulting from simultaneous involvement of suppliers and partners associated with the GSCM implementation process. Thus, firms should know that not only their relationship with suppliers but also good communication routines or sensing channels are critical to adapt to the changing business environment (i.e., green management).

GSCM positively affected firm performance. The results indicated that implementing GSCM is significantly beneficial to firms. GSCM practices positively affected environmental performance. This relationship can be expected as GSCM enables the firm to reduce environmental waste.

The relationship between the economic performance and GSCM practice was positive and strong. This relationship shows that the firm can obtain economic benefits from investing in GSCM. The results of our study among Korean manufacturing firms support the findings established by numerous studies. Suppliers, which implement green operations and satisfy green standards, are often selected as partners of multinational manufacturers that show positive relationships between GSCM practice and economic performance.

\section{Limitation and Future Research}

This study suggested dynamic capability as an antecedent of GSCM and proved a relationship between GSCM practice and organizational performance. In discussing our study results, we must mention the limitations of the study. First, the majority of sample firms were small and medium sized. These firms have adopted GSCM practice relatively recently, so their understanding of the concept might not have been clear. It will be useful to consider the minimum period of time that the firm implemented GSCM practice to be included in the sample. Second, we only considered the relationship between GSCM practice and the expected environmental and economic performance. We did not consider the relationship between environmental performance and economic performance because there are many common factors between GSCM practice and environmental performance, especially when data is collected based on survey method Real environmental and economic data were not available for our study. In the future, it is possible to find the relationship between real data and organizational performance, even considering the time lag between them. Also, by utilizing real data, investigating the relationship between environmental performance and economic performance may be result in implications for practitioners. Third, impact of market orientation on relational capability should be considered by including some moderating or control variables. These may reveal more significant results. Finally, due to the relatively small sample size, some fit indices were not as good as desired. A larger sample would increase statistical power and provide better fit. Overall, this study provided new insights into the growing field of the relationships between environmental operation practices and the performance of firms.

Author Contributions: B.S. and D.C. worked together in the process of writing the paper and analyzing the data. Funding: This research received no external funding.

Conflicts of Interest: The authors declare no conflict of interest.

\section{Appendix A}

Survey items

Dynamic capability

Market orientation

Customer knowledge

(1) Our business objectives are driven by customer satisfaction. 
(2) We closely monitor and assess our level of commitment in serving customers' needs.

(3) Our competitive advantage is based on understanding customer needs.

(4) We pay close attention to after-sale-service.

Competitor knowledge

(1) In our organization, our sales people share information about competitor information.

(2) We respond rapidly to competitive actions.

(3) We regularly discuss competitors' strengths and weaknesses.

(4) Customers are targeted when we have an opportunity for competitive advantage.

Relational capability

Relation-specific assets

(1) We rely on our partners' engineering capability.

(2) Partners' tools and machinery are customized to our needs.

(3) Our partners have dedicated significant investment and capacity to our relationship.

(4) Our partners' knowledge of our procedures, culture, and technological know-how is difficult to replace.

Inter-firm knowledge sharing routine

(1) Frequent contacts between our partners and our engineers are important.

(2) The direction of our communication is bilateral rather than unilateral.

(3) Our engineers and sales staff have close working relationships with our partners' staff.

(4) We share our high level engineering capability with our partner firms.

Green supply chain practice

Eco Design

(1) We design our products to avoid or reduce the use of hazardous products and their manufacturing process.

(2) We provide design specifications to partners that include environmental requirements for purchased items.

(3) We cooperate with partners for environmental objectives.

(4) We design our products for reuse, recycle, and recovery of material and component parts.

(5) We recommend partners to receive ISO 14000 certification.

Re-use and recycle

(1) We collect materials.

(2) We recycle materials.

(3) We manage or deal with waste.

Organizational Performance

Environmental performance

(1) Our $\mathrm{CO}_{2}$ emission has been reduced after the introduction of green policy.

(2) Our waste water has been reduced after the introduction of green policy.

(3) Our solid waste has been reduced after the introduction of green policy.

(4) Our energy consumption has been reduced after the introduction of green policy. 
Economic performance

(1) Our profitability has increased due to GSCM.

(2) Our market share has increased due to GSCM.

(3) Our sale growth rate has increased due to GSCM.

(4) Our earnings per share have increased due to GSCM.

\section{References}

1. Chu, S.H.; Yang, H.; Lee, M.; Park, S. The impact of institutional pressures on green supply chain management and firm performance: Top management roles and social capital. Sustainability 2017, 9, 764. [CrossRef]

2. Lee, S.-Y.; Klassen, R.D.; Furlan, A.; Vinelli, A. The green bullwhip effect: Transferring environmental requirements along a supply chain. Int. J. Prod. Econ. 2014, 156, 39-51. [CrossRef]

3. Carmina, L. Green Asia: 10 ways Asian Countries Are Getting More Eco-Friendly. CNN 2009. Available online: http:/ / travel.cnn.com/explorations/none/green-asia-10-ways-asian-countries-are-getting-moreecofriendly-367154/ (accessed on 1 June 2017).

4. Lee, S.-Y. Responsible supply chain management in the asian context: The effects on relationship commitment and supplier performance. Asia Pac. Bus. Rev. 2016, 22, 325-342. [CrossRef]

5. Perez-Valls, M.; Cespedes-Lorente, J.; Moreno-Garcia, J. Green practices and organizational design as sources of strategic flexibility and performance. Bus. Strategy Environ. 2016, 25, 529-544. [CrossRef]

6. Srivastava, S.K. Green supply-chain management: A state-of-the-art literature review. Int. J. Manag. Rev. 2007, 9, 53-80. [CrossRef]

7. Porter, M.E.; van der Linde, C. Green and competitive: Ending the stalemate. Harv. Bus. Rev. 1995, 73, 120-134.

8. Ko, W.W.; Liu, G. Environmental strategy and competitive advantage: The role of small-and medium-sized enterprises' dynamic capabilities. Bus. Strategy Environ. 2017, 26, 584-596. [CrossRef]

9. Hartmann, J.; Vachon, S. Linking environmental management to environmental performance: The interactive role of industry context. Bus. Strategy Environ. 2017, 27, 359-374. [CrossRef]

10. Bansal, P.; Roth, K. Why companies go green: A model of ecological responsiveness. Acad. Manag. J. 2000, $43,717-736$.

11. Kleindorfer, P.R.; Singhal, K.; Van Wassenhove, L.N. Sustainable operations management. Prod. Oper. Manag. 2005, 14, 482-492. [CrossRef]

12. Aragon-Correa, J.A.; Rubio-Lopez, E.A. Proactive corporate environmental strategies: Myths and misunderstandings. Long Range Plan. 2007, 40, 357-381. [CrossRef]

13. Jayaraman, V.; Klassen, R.; Linton, J.D. Supply chain management in a sustainable environment. J. Oper. Manag. 2007, 25, 1071-1074. [CrossRef]

14. Hofmann, K.H.; Theyel, G.; Wood, C.H. Identifying firm capabilities as drivers of environmental management and sustainability practices-evidence from small and medium-sized manufacturers. Bus. Strategy Environ. 2012, 21, 530-545. [CrossRef]

15. Klassen, R.D.; Whybark, D.C. The impact of environmental technologies on manufacturing performance. Acad. Manag. J. 1999, 42, 599-615.

16. Sharma, S.; Vredenburg, H. Proactive corporate environmental strategy and the development of competitively valuable. Strat. Manag. J. 1998, 19, 729-753. [CrossRef]

17. Clemens, B.; Douglas, T.J. Does coercion drive firms to adopt 'voluntary'green initiatives? Relationships among coercion, superior firm resources, and voluntary green initiatives. J. Bus. Res. 2006, 59, 483-491. [CrossRef]

18. Gavronski, I.; Klassen, R.D.; Vachon, S.; Nascimento, L.F.M. A resource-based view of green supply management. Transp. Res. Part E Logist. Transp. Rev. 2011, 47, 872-885. [CrossRef]

19. Chen, Y.-S.; Lin, Y.-H.; Lin, C.-Y.; Chang, C.-W. Enhancing green absorptive capacity, green dynamic capacities and green service innovation to improve firm performance: An analysis of structural equation modeling (sem). Sustainability 2015, 7, 15674-15692. [CrossRef]

20. Kabongo, J.D.; Boiral, O. Doing more with less: Building dynamic capabilities for eco-efficiency. Bus. Strategy Environ. 2017, 26, 956-971. [CrossRef]

21. Ramachandran, V. Strategic corporate social responsibility: A 'dynamic capabilities' perspective. Corp. Soc. Responsib. Environ. Manag. 2011, 18, 285-293. [CrossRef] 
22. Russo, M.V. Explaining the impact of iso 14001 on emission performance: A dynamic capabilities perspective on process and learning. Bus. Strategy Environ. 2009, 18, 307-319. [CrossRef]

23. Barney, J. Firm resources and sustained competitive advantage. J. Manag. 1991, 17, 99-120. [CrossRef]

24. Winter, S.G. Understanding dynamic capabilities. Strat. Manag. J. 2003, 24, 991-995. [CrossRef]

25. Reed, R.; DeFillippi, R.J. Causal ambiguity, barriers to imitation, and sustainable competitive advantage. Acad. Manag. Rev. 1990, 15, 88-102. [CrossRef]

26. Dangelico, R.M.; Pujari, D.; Pontrandolfo, P. Green product innovation in manufacturing firms: A sustainability-oriented dynamic capability perspective. Bus. Strategy Environ. 2017, 26, 490-506. [CrossRef]

27. Bowen, F.E.; Cousins, P.D.; Lamming, R.C.; Faruk, A.C. Horses for courses: Explaining the gap between the theory and practice of green supply. Greener Manag. Int. 2001, 35, 41-60. [CrossRef]

28. Lee, S.M.; Noh, Y.; Choi, D.; Rha, J.S. Environmental policy performances for sustainable development: From the perspective of iso 14001 certification. Corp. Soc. Responsib. Environ. Manag. 2017, 24, 108-120. [CrossRef]

29. Viscusi, W.K. Frameworks for analyzing the effects of risk and environmental regulations on productivity. Am. Econ. Rev. 1983, 73, 793-801.

30. Atasu, A.; Guide, V.D.R.; Van Wassenhove, L.N. Product reuse economics in closed-loop supply chain research. Prod. Oper. Manag. 2008, 17, 483-496. [CrossRef]

31. Helmers, L.R. The elastic green supply chain. World Trade 2008, 21, 24-25.

32. Zhu, Q.; Sarkis, J.; Cordeiro, J.J.; Lai, K.-H. Firm-level correlates of emergent green supply chain management practices in the chinese context. Omega 2008, 36, 577-591. [CrossRef]

33. Zhu, Q.; Sarkis, J. Relationships between operational practices and performance among early adopters of green supply chain management practices in chinese manufacturing enterprises. J. Oper. Manag. 2004, 22, 265-289. [CrossRef]

34. Liu, Y.; Zhu, Q.; Seuring, S. Linking capabilities to green operations strategies: The moderating role of corporate environmental proactivity. Int. J. Prod. Econ. 2017, 187, 182-195. [CrossRef]

35. Kainuma, Y.; Tawara, N. A multiple attribute utility theory approach to lean and green supply chain management. Int. J. Prod. Econ. 2006, 101, 99-108. [CrossRef]

36. Spangenberg, J.H.; Fuad-Luke, A.; Blincoe, K. Design for sustainability (dfs): The interface of sustainable production and consumption. J. Clean. Prod. 2010, 18, 1485-1493. [CrossRef]

37. Goosey, M. End-of-life electronics legislation-An industry perspective. Circuit World 2004, 30, 41-45. [CrossRef]

38. Goosey, M. Introduction and Overview. In Electronic Waste Management; Royal Society of Chemistry: Cambridge, UK, 2009; pp. 1-39.

39. Koufteros, X.A.; Edwin Cheng, T.C.; Lai, K.-H. "Black-box" and "gray-box" supplier integration in product development: Antecedents, consequences and the moderating role of firm size. J. Oper. Manag. 2007, 25, 847-870. [CrossRef]

40. Stevels, A. Green supply chain management much more than questionnaires and iso 14.001. In Proceedings of the 2002 IEEE International Symposium on Electronics and the Environment, San Francisco, CA, USA, 6-9 May 2002; pp. 96-100.

41. Cousins, P.D.; Handfield, R.B.; Lawson, B.; Petersen, K.J. Creating supply chain relational capital: The impact of formal and informal socialization processes. J. Oper. Manag. 2006, 24, 851-863. [CrossRef]

42. Dyer, J.H. Specialized supplier networks as a source of competitive advantage: Evidence from the auto industry. Strat. Manag. J. 1996, 17, 271-291. [CrossRef]

43. Prahinski, C.; Kocabasoglu, C. Empirical research opportunities in reverse supply chains. Omega 2006, 34, 519-532. [CrossRef]

44. Duber-Smith, D. The green imperative. Soap Perfum. Cosmet. 2005, 78, 24-26.

45. Chang, X.; Fan, J.; Zhao, Y.; Wu, J. Impact of china's recycling subsidy policy in the product life cycle. Sustainability 2016, 8, 781. [CrossRef]

46. Eisenhardt, K.M.; Martin, J.A. Dynamic capabilities: What are they? Strat. Manag. J. 2000, 21, $1105-1121$. [CrossRef]

47. Teece, D.; Pisano, G.; Shuen, A. Dynamic capabilities and strategic management. Strat. Manag. J. 1997, 18, 509-533. [CrossRef]

48. Zahra, S.A.; Sapienza, H.J.; Davidsson, P. Entrepreneurship and dynamic capabilities: A review, model and research agenda. J. Manag. Stud. 2006, 43, 917-955. [CrossRef] 
49. Zahra, S.; Ireland, R.; Hitt, M. International expansion by new venture firms: International diversity, mode of market entry, technological learning, and performance. Acad. Manag. J. 2000, 43, 925-950.

50. Prahalad, C.K.; Hamel, G. The core competence of the corporation. Harv. Bus. Rev. 1990, 68, 79-91.

51. Zollo, M.; Winter, S.G. Deliberate learning and the evolution of dynamic capabilities. Organ. Sci. 2002, 13, 339-351. [CrossRef]

52. Ahuja, G.; Lampert, C.M. Entrepreneurship in the large corporation: A longitudinal study of how established firms create breakthrough inventions. Strat. Manag. J. 2001, 22, 521-543. [CrossRef]

53. Katila, R.; Ahuja, G. Something old, something new: A longitudinal study of search behavior and new product introduction. Acad. Manag. J. 2002, 45, 1183-1194.

54. Helfat, C.E.; Finkelstein, S.; Mitchell, W.; Peteraf, M.A.; Singh, H.; Teece, D.J.; Winter, S.G. Dynamic Capabilities: Understanding Strategic Change in Organizations; Wiley-Blackwell: Hoboken, NJ, USA, 2007.

55. Ho, Y.-C.; Tsai, T.-H. The impact of dynamic capabilties with market orientation and resource-based approaches on npd project performance. J. Am. Acad. Bus. Camb. 2006, 8, 215-229.

56. Menguc, B.; Auh, S. Creating a firm-level dynamic capability through capitalizing on market orientation and innovativeness. J. Acad. Mark. Sci. 2006, 34, 63-73. [CrossRef]

57. McCutcheon, D.; Stuart, F.I. Issues in the choice of supplier alliance partners. J. Oper. Manag. 2000, 18, $279-301$. [CrossRef]

58. Luzzini, D.; Brandon-Jones, E.; Brandon-Jones, A.; Spina, G. From sustainability commitment to performance: The role of intra-and inter-firm collaborative capabilities in the upstream supply chain. Int. J. of Prod. Econ. 2015, 165, 51-63. [CrossRef]

59. Powell, W.W.; Koput, K.W.; Smith-Doerr, L. Interorganizational collaboration and the locus of innovation: Networks of learning in biotechnology. Adm. Sci. Q. 1996, 41, 116-145. [CrossRef]

60. Krause, D.R.; Handfield, R.B.; Tyler, B.B. The relationships between supplier development, commitment, social capital accumulation and performance improvement. J. Oper. Manag. 2007, 25, 528-545. [CrossRef]

61. Petersen, K.J.; Handfield, R.B.; Ragatz, G.L. Supplier integration into new product development: Coordinating product, process and supply chain design. J. Oper. Manag. 2005, 23, 371-388. [CrossRef]

62. Primo, M.A.M.; Amundson, S.D. An exploratory study on the effects of supplier relationships on new product development outcomes. J. Oper. Manag. 2002, 20, 33-52. [CrossRef]

63. Grant, R.M. Toward a knowledge-based theory of the firm. Strat. Manag. J. 1996, 17, 109-122. [CrossRef]

64. Todorova, G.; Durisin, B. Absorptive capacity: Valuing a reconceptualization. Acad. Manag. Rev. 2007, 32, 774-786. [CrossRef]

65. Hauptman, O. Influence of task type on the relationship between communication and performance: The case of software development. $R$ D Manag. 1986, 16, 127-139. [CrossRef]

66. Katz, R.; Tushman, M. Communication patterns, project performance, and task characteristics: An empirical evaluation and integration in an r\&d setting. Organ. Behav. Hum. Perform. 1979, 23, 139-162.

67. Dyer, J.H.; Singh, H. The relational view: Cooperative strategy and sources of interorganizational competitive advantage. Acad. Manag. Rev. 1998, 23, 660-679. [CrossRef]

68. Mesquita, L.F.; Brush, T.H. Untangling safeguard and production coordination effects in long-term buyer-supplier relationships. Acad. Manag. J. 2008, 51, 785-807.

69. Han, J.; Kim, N.; Srivastava, R. Market orientation and organizational performance: Is innovation a missing link? J. Mark. 1998, 62, 30-45. [CrossRef]

70. Slater, S.; Narver, J. Does competitive environment moderate the market orientation-performance relationship? J. Mark. 1994, 58, 46-55. [CrossRef]

71. Connor, T. Market orientation and performance. Strat. Manag. J. 2007, 28, 957-959. [CrossRef]

72. Atuahene, G.; Slater, S.; Olson, E. The contingent value of responsive and proactive market orientations for new product program performance. J. Prod. Innov. Manag. 2005, 22, 464-482. [CrossRef]

73. Narver, J.; Stanley, F.S. The effect of a market orientation on business profitability. J. Mark. 1990, 54, $20-35$. [CrossRef]

74. Slater, S.F.; Narver, J.C. Market orientation and the learning organization. J. Mark. 1995, 59, 63-74. [CrossRef]

75. Stanley, F.S.; Narver, J. Market Orientation, customer value, and superior performance. Bus. Horizons. 1994, 37, 22-29.

76. Griffith, D.A.; Harvey, M.G.; Lusch, R.F. Social exchange in supply chain relationships: The resulting benefits of procedural and distributive justice. J. Oper. Manag. 2006, 24, 85-98. [CrossRef] 
77. Peteraf, M.A.; Bergen, M.A. Scanning dynamic competitive landscapes: A market-based and resource-based framework. Strat. Manag. J. 2003, 24, 1027-1041. [CrossRef]

78. Narver, J.C.; Slater, S.F.; MacLachlan, D.L. Responsive and proactive market orientation and new-product success. J. Prod. Innov. Manag. 2004, 21, 334-347. [CrossRef]

79. Hult, G.T.M.; Ketchan, D.J. Does market orientation matter?: A test of the relationship between positional advantage and performance. Strat. Manag. J. 2001, 22, 899-906. [CrossRef]

80. Zaheer, S. Overcoming the liability of foreignness. Acad. Manag. J. 1995, 38, 341-363.

81. Schaltegger, S.; Burritt, R. Measuring and managing sustainability performance of supply chains: Review and sustainability supply chain management framework. Supply Chain Manag. Int. J. 2014, 19, 232-241. [CrossRef]

82. Tsoulfas, G.T.; Pappis, C.P. A model for supply chains environmental performance analysis and decision making. J. Clean. Prod. 2008, 16, 1647-1657. [CrossRef]

83. Wu, L.; Subramanian, N.; Abdulrahman, M.D.; Liu, C.; Lai, K.-H.; Pawar, K.S. The impact of integrated practices of lean, green, and social management systems on firm sustainability performance-Evidence from chinese fashion auto-parts suppliers. Sustainability 2015, 7, 3838-3858. [CrossRef]

84. Berry, M.A.; Rondinelli, D.A. Proactive corporate environmental management: A new industrial revolution. Acad. Manag. Exec. 1998, 12, 38-50. [CrossRef]

85. Rao, P.; Holt, D. Do green supply chains lead to competitiveness and economic performance? Int. J. Oper. Prod. Manag. 2005, 25, 898-916. [CrossRef]

86. Jacobs, B.W.; Singhal, V.R.; Subramanian, R. An empirical investigation of environmental performance and the market value of the firm. J. Oper. Manag. 2010, 28, 430-441. [CrossRef]

87. Hart, S.L. A natural-resource-based view of the firm. Acad. Manag. Rev. 1995, 20, 986-1014. [CrossRef]

88. Boyer, K.; Olson, J.; Calantone, R.; Jackson, E. Print versus electronic surveys: A comparison of two data collection methodologies. J. Oper. Manag. 2002, 20, 357-373. [CrossRef]

89. Bagozzi, R.; Yi, Y. On the evaluation of structural equation models. J. Acad. Mark. Sci. 1988, 16, 74-94. [CrossRef]

90. Jöreskog, K. A general approach to confirmatory maximum likelihood factor analysis. Psychometrika 1969, 34, 183-202. [CrossRef]

91. Shook, C.; Ketchen, D.; Hult, G.; Kacmar, K. Research notes and commentaries: An assessment of the use of structural equation modeling in strategic management research. Strat. Manag. J. 2004, 25, 397-404. [CrossRef]

92. Sivo, S.; Fan, X.; Witta, E.; Willse, J. The search for" optimal" cutoff properties: Fit index criteria in structural equation modeling. J. Exp. Educ. 2006, 74, 267-288. [CrossRef]

93. Fornell, C.; Larcker, D.F. Structural equation models with unobservable variables and measurement error: Algebra and statistics. J. Mark. Res. 1981, 18, 382-388. [CrossRef]

94. Fornell, C.; Larcker, D. Evaluating structural equation models with unobservable variables and measurement error. J. Mark. Res. 1981, 18, 39-50. [CrossRef]

95. Jaworski, B.J.; Kohli, A.K. Market orientation: Antecedents and consequences. J. Mark. 1993, 57, 53-70. [CrossRef] 